\title{
COMMENTS
}

\section{THE MEASURE OF DAMAGES FOR WRONGFUL DISHONOR}

The measure of damages for a debtor's failure to pay a liquidated sum is the amount owed plus interest. ${ }^{1}$ Although the relationship of a bank to its depositors is that of debtor and creditor, this rule is seldom applied in an action by the depositor arising out of a bank's failure to pay to his order. In the recent California case of Abramowitz v. Bank of America ${ }^{2}$ it was held that the statute defining tort damages provided the proper measure of recovery in such an action. ${ }^{3}$ The question of how such a discrepancy in the measure of damages came to be and the reasons for the discrepancy form the subject matter of this comment.

In the Abramowitz case the action was for damages sustained because plaintiff's check, representing the monthly installment on his car, was wrongfully dishonored, resulting in the repossession and sale of the car. The court upheld a recovery of $\$ 731.80$ plus interest saying that if he had asked for it plaintiff could have received $\$ 1,600$, the full resale value of the car. ${ }^{4}$ The court justified its departure from the existing liquidated damages rule, ${ }^{5}$ by

${ }^{2} 5$ Williston, Contracts $\$ 1410$ (rev. ed., 1937).

2131 Cal. App. 2d 892, 281 P. 2d 380 (Super. Ct., 1955).

3 "For the breach of an obligation not arising from contract, the measure of damages, except where otherwise expressly provided by this code, is the amount which will compensate for all the detriment proximately caused thereby, whether it could have been anticipated or not." Cal. Civ. Code (Deering, 1949) $\$ 3333$.

"The $\$ 731.80$ was found by adding the sum of the plaintiff's previous payments $(\$ 935.00)$ to the difference between what he still owed $(\$ 2,196.80)$ and the amount realized on the re-sale $(\$ 1,600.00)$, and taking from this the $\$ 800.00$ which represented his estimated enjoyment of the car. The defendant argued that since the market value of the car was less than the plaintiff still owed, that the plaintiff had suffered no harm. The court answered that the plaintiff could have recovered the full market value of the car since he was still liable over to the dealer.

${ }^{5}$ This was the holding of Flartford v. All Night \& Day Bank, 170 Cal. 538, 150 Pac. 356 (1915). In that case the plaintiff had been arrested following the dishonor of his check. He claimed that the bank's negligence was the proximate cause of his arrest. The court held against him on three counts: (1) the facts did not support the charge of negligence, (2) the action was governed by the statute limiting damages to the amount owed plus interest in cases of a failure to pay a liquidated sum, and (3) the payee's action in having the plaintiff arrested was an intervening cause and the bank therefore could not be the proximate cause of the arrest. The case became the leading case for this last proposition, which is discussed in the text at p. 491 infra. 
stating that the statute covering a bank's liability for the wrongful dishonor of a check ${ }^{6}$ had changed the action from one in contract to one in tort. The act reads:

No bank shall be liable to a depositor because of the nonpayment through mistake or error, and without malice, of a check which should have been paid unless the depositor shall allege and prove actual damage by reason of such nonpayment and in such event the liability shall not exceed the amount of damage so proved. ${ }^{7}$

The court interpreted the phrase "actual damage" as an implied mandate that damages were to be limited only by the tort rule of proximateness.

The statute in question is substantially the same as that proposed by the American Banker's Association in $1914 .^{8}$ In the words of the commentator its purpose was

to correct the unjust rule established by the courts in many states to the effect that a bank, which refuses to pay the check of a customer who is a merchant or trader and who has sufficient funds on deposit, is liable to such drawer in an action for substantial damages, without proof of actual damage or any malice on the part of the bank. ... The courts proceed on the theory that the dishonor of his check must necessarily result in material injury to such drawer and therefore hold that the law will conclusively presume such to be the fact without the necessity of any proof thereof. But the fact is often contrary to the presumption.... [T] he bank ... is often mulcted in damages out of all proportion to the imaginary injury inflicted. ... ${ }^{9}$

The presumption which the commentator referred to is similar to that in libel or slander per se and was created by analogy to the slander of trade action. ${ }^{10}$

Since the statute was originally sponsored by the American Banker's Association, the use of it in the Abramowitz case to extend liability was undoubtedly not the anticipated consequence. The reason for this anomalous result is that the draftsman, who intended only to eliminate a presumption of damages, inadvertently drew the statute so that it could also be read as changing the elements of damages. A court, in construing the statute, could confine itself,

${ }^{\circ}$ Cal. Civ. Code (Deering, 1949) $\$ 3320$.

${ }^{7}$ Ibid.

8 "No bank or trust company doing business in this State shall be liable to a depositor because of the non-payment through mistake or error and without malice of a check which should have been paid unless the depositor shall allege and prove actual damage by reason of such non-payment and in such event the liability shall not exceed the amount of damage so proved." I Paton's Digest 1117 (1940).

The statute appears to have been a codification of T. B. Clark Co. v. Mt. Morris Bank, 85 App. Div. 362, 83 N.Y. Supp. 447 (1st Dep't, 1903), aff'd 181 N.Y. 533, 73 N.E. 1133 (1905). Recovery was denied in that case because the dishonor was due to an "inadvertence" on the part of the bookkeeper; the court held that in the absence of malice only nominal damages can be awarded.

'I Paton's Digest 1117 (1940).

${ }^{10}$ Rolin v. Stewart, 14 C.B. 595 (1854). 
as the California court did, to defining the phrase "actual damages," thereby changing the type of damages recoverable. This entirely ignores the words which the draftsman would consider crucial: "allege and prove." The California court's approach was defensible, however, because in that state the liquidated sum rule was followed prior to the passage of the statute ${ }^{11}$ and therefore the statute could not be read as intending to eliminate a presumption of damages. ${ }^{12}$ Its only possible effect therefore was to cause a departure from the narrow limits of the liquidated sum rule.

The court then had to decide how far damages should be extended. It had three alternatives from which to choose: (1) ordinary contract damages measured by foreseeability, (2) slander of credit damages or (3) ordinary tort damages. The court chose the last alternative; but to understand the full significance of the decision it is necessary to examine each of the alternatives. $^{13}$

Some courts have measured damages by the rule of Hadley $v$. Baxendale, ${ }^{14}$ i.e., damages reasonably foreseeable at the time the contract was made. ${ }^{15}$ If

${ }^{11}$ The rule was applied in Hartford v. All Night \& Day Bank, 170 CaI. 538, 150 Pac. 356 (1915); the statute was passed in 1917, Cal. Stat. (1917) c. 503.

${ }^{12}$ In construing the statute other courts have confined their efforts to finding a meaning of "actual damages" although they were not faced with the situation confronting the California court. In First Nat'l Bank of Mobile v. Ducros, 27 Ala. App. 193, 168 So. 704 (1936), the court decided that "actual" simply meant existent damages and said that the statute was "but a statutory statement of the broad general rule that a wrongdoer is liable . . . for all the natural and direct or proximate consequences of his wrongful act or omission, and conversely ... he is liable only for such consequences." Ibid., at 195 and 705. Apparently it did not occur to the court that the statute was intended to do away with a presumption of damages because it made reference to the distinction between traders and non-traders. To avoid such a nullifying interpretation, which was being urged on it by the plaintiff, the court in Bush v. Southwark Nat'l Bank, 8 Pa. D. \& C. 27 (1926), decided that "actual damages" meant "special damages" as that phrase is used in the law of slander to limit recovery to pecuniary losses. Consult the text at p. 486 infra.

${ }^{13}$ The court posed the question as if the only choice were between tort damages and the liquidated sum rule. Ordinary contract damages were mentioned only in answer to the defendant's contention that the loss of the car was not recoverable. The court, at 896 and 383 , said that there is a distinction between contract and tort damages in that in the latter "damages not even anticipated are recoverable." It did not consider foreseeable damages as a possible alternative measure, although certainly they too are "actual damages."

14 9 Ex. 341 (1854).

${ }^{15}$ E.g., Meyer v. Hudson Trust Co., 181 App. Div. 69, 168 N.Y. Supp. 387 (1st Dep't, 1917). The New York courts never hesitated to apply to this action a contract rule of damages other than the liquidated sum rule. This is probably because they consider that the essence of the bank's obligation is to pay to the order of the depositor. For example in Burroughs v. Tradesmen's Nat'l Bank, 87 Hun (N.Y.) 6, 33 N.Y. Supp. 864 (2d Dep't, 1895), the court said that the contract "is that the bank will hold the funds, and pay them out according to the order of the depositor." Ibid., at 7 and 865 . The use of the liquidated sum rule in the wrongful dishonor context is probably a result of too strict an application of the dogma that the relationship between the bank and its depositor is that of debtor and creditor. 
this rule were realistically applied the results would be no more satisfactory than those under the liquidated sum rule since the bank generally has no idea of and no interest in the purposes for which the depositor opens his account. Even if the rule is misapplied so that the damages reasonably foreseeable at the time of dishonor are held to be recoverable the results are not likely to be materially different. ${ }^{16}$ At the time of dishonor the bank will not ordinarily have any more information as to the purposes for which the depositor is using his account than it had at the time the account was opened. Although the rule of Hadley v. Baxendale is not generally applied so harshly that specific injuries must be foreseeable, ${ }^{17}$ it would have to be moderated out of existence before any damages could be recovered in the wrongful dishonor cases. The rule is peculiarly unsuitable for institutions which daily make a great number of impersonal contracts with the public. ${ }^{18}$

It is notable that the California court did not allude to the law of defamation because the historic remedy for the wrongful dishonor of a check has been an action for "slander of credit." The leading case is Rolin v. Stewart, ${ }^{19}$

${ }^{16}$ In Wahrman v. Bronx County Trust Co., 246 App. Div. 220, 285 N.Y. Supp. 312 (1st Dep't, 1936), the court, in refusing recovery to the plaintiff who had lost his insurance policy because of the defendant's wrongful dishonor of his check, said, "it is necessary for the plaintiff to allege and establish that the defendant had actual or constructive knowledge of the consequences reasonably to be expected from the non-payment of the check. Such knowledge cannot be inferred merely from the fact that the check was payable to an insurance company." Ibid., at 221 and 313. Contra: Roe v. Best, 120 S.W. 2d 819 (Tex. Civ. App., 1938).

${ }^{17} 5$ Corbin, Contracts $\$ 1012$ (1951).

${ }^{18}$ In other enterprises which deal with large segments of the public, tort damages are sometimes applied even though the relationship arises out of a contract. For example, in an action by a passenger against a railroad for injuries suffered because of a negligent breach of its contract to carry him safely to his destination, the action can sound in tort. AustroAmerican S.S. Co. v. Thomas, 248 Fed. 231 (C.A. 2d, 1917); 13 C.J.S., Carriers $\$ 640$ (1939). This rule was applied with some hesitation and dissension in several earlier cases. For example in Cincinnati H. \& I. R. Co. v. Eaton, 94 Ind. 474 (1883), the court held that injuries sustained by plaintiff after she had been let off at the wrong station, though too remote to be recovered in contract, were recoverable in tort because the contract relationship had ended when they passed the station where she should have been let off. The court, however, cited for authority Brown v. Chicago, Milwaukee \& St. Paul Ry. Co., 54 Wis. 342,11 N.W. 356 (1882), a case similar in facts, but in which the court held the tort measure of damages applicable without resorting to such technical arguments. Consult also the dissenting opinion in Baltimore City Pass. Ry. Co. v. Kemp, 61 Md. 74 (1883).

Unlike the railroads, the contract measure of damages is applied to telegraph companies when they negligently fail to deliver a telegram accurately. 86 C.J.S., Telegraphs and Telephones $\$ 208$ (1954). But Judge Cardozo in Kerr S.S. Co. v. Radio Corp. of America, 245 N.Y. 284,157 N.E. 140 (1927), indicated some uneasiness with the application of the doctrine in this context: "We are not unmindful of the force of the plaintiff's assault upon the rule in Hadley v. Baxendale in its application to the relation between telegraph carrier and customer. The truth seems to be that neither the clerk who receives the message over the counter nor the operator who transmits it nor any other employee gives or is expected to give any thought to the sense of what he is receiving or transmitting. This imparts to the whole doctrine as to the need for notice an air of unreality." Tbid., at 291 and 142.

${ }^{10} 14$ C.B. 595 (1854). 
decided in England in 1854. In that case the declaration stated that the plaintiffs", whose checks had been dishonored, were "merchants and shipowners" and that they had been "greatly injured in their credit and circumstances, and were suspected . . . to be in bad, failing, and insolvent circumstances." ${ }^{\text {20 }}$ Although no proof of damage was offered the court upheld an instruction to the jury that it "should give the plaintiffs such temperate damages as they should judge to be a reasonable compensation for the injury [the plaintiffs'] must have sustained from the dishonour of their cheques."21

The defendant had argued that the action was substantially one in contract, and that since no "special damages" had been proved the plaintiff could only recover nominal damages. William, J., said that "the fact of his being in trade stands in the place of special damage."22 By "special" the court apparently meant damages which had been proved to some degree of certainty. The case thus stands for the proposition that from the fact of the dishonor of a trader's check the fact of damage is presumed and the jury is free to award damages within the general limitations of substantial but temperate amounts. ${ }^{23}$

This decision was the result of a practice which is not common in American banking - the overdraft as a means of extending credit. ${ }^{24}$ The court felt that this system made for a great probability of damages. This is evident from the

"Ibid., at 597 .

m Ibid, at 599.

22 Ibid., at 603.

23 There is nothing in the decision to indicate that the presumption thus established was a conclusive presumption, as the commentary to the Banker's Statute stated. (See text at p. 482 supra.) On the contrary, the court, in distinguishing an earlier case, Marzetti v. Williams, 1 B. \& AId. 415 (1830), in which only nominal damages had been given, said that the check in that case was paid the next day and that it "seems to have been taken for granted that the plaintiff had sustained no actual damage." This indicates that in English courts the presumption of damages was rebuttable.

The only case found holding that there is a conclusive presumption of damages is First Nat'l Bank v. McFall \& Co., 144 Ark. 149, 222 S.W. 40 (1920), which is of somewhat doubtful authority. The defendant bank appealed from an award of $\$ 500.00$ given to a grocer whose check it had dishonored. The court held the presumption to be conclusive and that the trial judge correctly refused an instruction that the presumption was rebuttable. It asserted that the foundation of the presumption was that damages were usually impossible to prove. Conversely it was irrebuttable because it was impossible to prove no damages.

But the court in that case had been forced into this unconvincing position by a dissent written by McCulloch, C.J., in McFall v. First Nat'l Bank of Forest City, 138 Ark. 370, 211 S.W. 919 (1919), where the plaintiff successfully appealed the trial court's refusal of an instruction on the presumption of damages rule. The dissent insisted that such an instruction was a comment on the weight of the evidence which an Arkansas statute prohibited judges from doing. The court when faced with the issue again had to rule that it was not a rule of evidence but a rule of substantive law.

${ }^{2}$ Evitt, Practical Banking 16 (4th ed., 1937). In Thomson v. Nat'l Bank Ltd., 71 Ir. L.T.R. 142 (1937), the bank dishonored an overdraft and was held liable for injury to plaintiff's credit as a trader "ensuing upon the dishonour of a comparatively small cheque." Ibid., at 146. 
language of Lord Tenterden, C.J., in Marzetti v. Williams, ${ }^{25}$ which was quoted with approval in the Rolin case: "I cannot forbear to observe, that it is a discredit to a person, and therefore injurious in fact, to have a draft refused payment for so small a sum, for it shews that the banker had very little confidence in the customer."26

The court in the Rolin case did not go so far as to say that the remedy for the wrongful dishonor of a check is an action for slander of trade. It merely used slander of trade as an analogy to establish a presumption of damages. Nevertheless, because this was thought of as a slander action, subsequent American courts adopted other rules of damages from the law of defamation such as the one that in slander pecuniary damages must be shown if it is not actionable per se. In ordinary slander this rule has led to harsh results when strictly applied ${ }^{27}$ and to inconsistencies when not. ${ }^{28}$ Efforts to temper the rule have caused so much uncertainty that it is impossible to define clearly "pecuniary" loss. ${ }^{29}$ Similarly unsatisfactory results have followed from its application to the wrongful dishonor cases.

In Bush v. Southwark Nat'l Bank ${ }^{30}$ the Pennsylvania court, in construing the Banker's Statute, looked to the law of defamation to find the meaning of "actual" damages. It decided that it was synonymous with "special damages," as that phrase is used in the law of slander and that it meant that only pecuniary damages were recoverable. The court reasoned that the action was originally defamation per se, and that the statute had changed it into simple slander. Under this theory it refused recovery to a merchant who had shown impairment of credit, saying that this was only an inconvenience.

The court in the Bush case relied on State Bank of Siloam Springs v. Marshall, ${ }^{31}$ an Arkansas case, for the proposition that damage to credit is only an inconvenience. Apparently the court did not notice that the court in the

${ }^{25} 1$ B. \& Ald. 415 (1830).

${ }^{28}$ Ibid., at 424.

${ }^{z}$ In Clark v. Morrison, 80 Ore. 240, 156 Pac. 429 (1916), a demurrer to plaintiff's complaint that the slander had caused her illness resulting in a two week hospitalization was upheld on the grounds that no "special" damages had been alleged.

${ }^{23}$ Compare Clark v. Morrison, ibid., with Underhill v. Welton, 32 Vt. 40 (1859), in which the court held that a claim that due to the distress following the slander the plaintiff suffered loss of time and was "prevented and disabled from pursuing her accustomed duties and labors with the strength and health that she otherwise would have enjoyed," (ibid., at 42) was an allegation of pecuniary loss.

${ }^{2}$ The Restatement defines pecuniary loss as including harm to property, harm to earning capacity and the creation of liabilities. Rest., Torts $\$ 906$ (1939). The provision allowing injury to earning capacity as a pecuniary loss could be used to extend the number of actionable slanders. Generally an allegation of mental distress or physical injury by itself has been held not actionable, Prosser, Torts 806 (1941), but it seems that such injuries could often be construed as injury to earning capacity.

${ }^{30} 8$ Pa. D. \& C. 27 (1926).

st 163 Ark. 566, 260 S.W. 431 (1924). 
Marshall case was careful to show that the plaintiff, a boardinghouse keeper, was not a trader or merchant. The Marshall case contained a dictum to the effect that if a trader were to show impairment of credit, it would be taken as proof of pecuniary loss.

Another variation is found in Valley Nat'l Bank v. Witter, ${ }^{32}$ an Arizona case in which the court was not faced with a statute. It said that the action was similar to slander and held that the presumption could apply although the plaintiff was a non-trader. It allowed special damages, attorney's fees and phone calls, to be added to the general damages to credit, but it refused damages for mental suffering because recovery was limited to "monetary" losses. Apparently the court had no doubt that injury to credit was a pecuniary loss.

Besides this difficulty resulting from the technicalities of the law of defamation, the modern justifications given for the presumption of damages are highly questionable. The argument based on the probability of damages is not so convincing in this country because American banks do not use overdrafts as a means of extending credit. In England when a check is dishonored the conclusion is almost inescapable that the bank does not wish to extend the depositor any credit, or at least any more credit. In the United States the payee may and may not draw adverse conclusions from the fact of dishonor for insufficient funds; for example, if he is acquainted with the delays involved in the collection process he may attribute the dishonor, as one possible explanation at least, to the fact that some items deposited by the drawer may not yet have cleared. While the probability of substantial injury to a drawer's reputation cannot be measured with great accuracy, it would not seem to be so high as to justify turning the case over to the jury on the mere allegation of dishonor. ${ }^{33}$

Evidence that some of the courts have lost sight of the probability of damage rationale for the presumption is found in the fact that they have extended the rule to apply to non-traders as well. ${ }^{34}$ This extension is justified on the theory that the ordinary man customarily has a bank account now, whereas formerly checks were used principally in commerce. This argument is selfdefeating because the smaller the number of non-business accounts there are, the less pressing is the need to make a distinction, and furthermore the likelihood of extensive damages to a private individual seems far too speculative to allow the presumption. ${ }^{35}$

${ }^{32} 58$ Ariz. 491, 121 P, 2d 414 (1942).

ss Consult note 43 infra.

st Consult, e.g., Valley Nat'l Bank v. Witter, 58 Ariz. 491, 121 P. 2d 414 (1942); Woody v. Nat'l Bank of Rocky Mount, 194 N.C. 549, 140 S.E. 150 (1927).

${ }^{25}$ The presumption relieves the plaintiff of two burdens-the burden of coming forward with evidence of the fact of damage and of the amount. This is in direct conflict with the general American doctrine that both the fact and the amount of damages must be proved 
Underlying the presumption of damages rule is the assumption that credit standing is a matter of hearsay. This is another reason for abandoning the rule because the fact is that the evaluation of credit standing is now a highly organized business. Dunne \& Bradstreet and the local credit bureau are the usual sources of information of those faced with a decision involving the solvency or trustworthiness of a person or firm. In case of a wrongful dishonor many adverse effects could generally be stopped by a communication from the bank to these agencies.

It could be argued that the presumption is necessary since damages are extremely difficult to prove. This argument has been advanced in defense of the presumption in defamation per se cases. ${ }^{36}$ Injury to credit, however, is more susceptible to proof than general injury to reputation. For example, it can be shown, as was done in some cases following the passage of the American Banker's Association statute, that the plaintiff was subsequently refused credit by people who had formerly extended it to him. ${ }^{37}$ Although the Banker's Statute is open to criticism in terms of its draftsmanship, the effort to eliminate the presumption of damages was justified. ${ }^{38}$ Since the slander

to some degree of certainty. McCormick, Damages $\$ \S 25,26$ (1935). On the other hand, in England the standard is much less stringent: "Questions of certainty, likewise, are subordinated by the tendency of the English judges to treat the measurement of damages generally as a matter for the jury's discretion." Ibid., at 98. Consult also Mayne on Damages, 559 (10th ed., 1927).

In the light of this difference in general approach it could be said that although the doctrine was a natural development in England, it fits uncomfortably into the American treatment of damages.

${ }^{38}$ Consult, e.g., Prosser, Torts 808 (1941).

${ }^{37}$ Bush v. Southwark Nat'l Bank, 8 Pa. D. \& C. 27 (1926); State Bank of Siloam Springs v. Marshall, 163 Ark. 566, 260 S.W. 431 (1924).

${ }^{33}$ The Uniform Commercial Code has a section which is similar to the Banker's Statute: "A payor bank is liable to its customer for wrongful dishonor of an item but where the dishonor occurs through mistake its liability is limited to the actual damages proved including damages for any arrest or prosecution of the customer." $\$ 4-402$ (Official Draft, 1952). The comment specifically refuses to set forth a theory of the action, but an analysis of the statute together with the comment demonstrates that its effect should be the same as that proposed in the text, i.e., the action should be treated as a tort independent of contract or defamation rules.

The comment states that it is intended to end the presumption of damages based on the defamation per se theory. Now if, in spite of this, the action were still to be treated as a defamation action, then pecuniary loss would have to be alleged and proved before any non-pecuniary losses were allowed because such losses are only allowed as "parasitic" damages to the pecuniary damages. Prosser, Torts 806 (1941). But arrest and prosecution are not pecuniary losses and the statute specifically provides for their recovery and implies that other non-pecuniary losses are also recoverable.

The statement that a bank's "liability is limited to actual damages proved" suggests that there are no other limits besides the necessary one of proximateness. In other words, the limitation set forth is exhaustive and by implication excludes such limitations as are imposed by contract principles, i.e., the requirements that the injury must be foreseeable or 
analogy was originally used only to create the presumption, there is no reason that the archaic rules of defamation should survive the presumption. ${ }^{30}$ If they do there is a shift from one extreme to another: if the presumption is applied the plaintiff is relieved of all burdens in relation to damages; on the other hand if the action continues to be treated as slander when the presumption is dropped, the plaintiff nust undertake the onerous burden of proving pecuniary loss. ${ }^{40}$

the natural consequence of the wrong. (Note that this argument also rejects the defamation requirement that the loss must be pecuniary.)

Another argument can be made against a contract theory of damages based again on the fact that damages for arrest or prosecution are specifically allowed even in cases where the dishonor was due to a mistake and therefore was not malicious. The essence of these injuries is mental suffering and ordinarily mental suffering is not a compensable injury in a suit for breach of contract unless the breach was malicious. Consult Rest., Contracts $\$ 341$ (1932).

The provision which limits liability only if the dishonor is due to mistake, is comparable to that in the A.B.A. statute limiting it only when it occurs through "mistake or error, and without malice" (note 8 supra). It is generally considered a "mistake" when through a bookkeeping error the check is dishonored; it is not a "mistake" if the bank refuses to honor the check because of an adverse claim, Wildenberger v. Ridgewood Nat'l Bank, 230 N.Y. 425,130 N.E. 600 (1921), or because it thinks it has a claim on the deposit, Jones v. Citizen's Bank of Clovis, 58 N.M. 48, 265 P. 2d 366 (1954). This seems to indicate that the difference is between dishonor occurring through negligence and dishonor because of a mistake of law as to the bank's rights. But cf. Gonsalves v.'Bank of America, $16 \mathrm{Cal}$. 2d 169,105 P. $2 \mathrm{~d} 118$ (1940). It seems that the use of the word "negligence" would have been preferable to "mistake," although the idea of a bank trying to prove that it was negligent to limit its liability seems anomalous.

It is questionable, however, whether the distinction should be made at all, especially when the bank is faced with an adverse claim. In this situation, if there is no adverse claim statute, the bank is liable to the claimant if it honors the check and the claim turns out to be valid; on the other hand, if it dishonors any checks and the claims are not valid, it is liable to the depositor for wilful dishonor. It is understandable why the draftsman wanted to prevent banks from claiming deposits with impunity, but for this purpose punitive damages would seem more appropriate. The distinction is further questionable because in case of a "wilful" dishonor both the code and the statute leave the parties to their common-law remedies which vary in difierent states. For example, not all states allow the presumption of damages to work in favor of both traders and non-traders. In a jurisdiction like California, where the liquidated sum rule was the law before the Banker's statute, the court could not return to its common-law rule since it would then have to allow less damages for willful dishonor than for an inadvertent dishonor. The distinction would thus compel the court, in willful dishonor cases, to choose one of the various rules as to the presumption of damages.

${ }^{30}$ This requirement of a pecuniary loss is a result of a jurisdictional dispute between the ecclesiastical and the common-law courts. The latter, in order to show that they were limiting themselves to temporal afiairs, required a showing of pecuniary loss. The Pre-Thorley v. Kerry Case Law of the Libel-Slander Distinction, 23 U. of Chi. L. Rev. 132, 134-36 (1955).

${ }^{*}$ Even if the damage alleged in a complaint is injury to reputation or credit it is not necessary to apply the rules of defamation. Since this is basically a contract, no tort damages need to be allowed at all, and if for special reasons the courts decide to allow them they should be free to frame an action which will best satisfy those reasons and not be 
In view of the harshness or inconsistency resulting from either a contract measure of damages or the defamation rules, the court's decision in the Abramowitz case to treat this as a tort sui generis seems to be a wise one. The court's decision on this point was so unequivocal that it suggests a deliberate attempt to rid the action of any vestiges of slander or contract rules. This decisiveness is desirable because in several prior cases the courts have shown a lack of precision in the use of the proximate cause measure of damages. The uncertainty as to the nature of the wrongful dishonor action has undoubtedly contributed to this imprecision. Thus some courts, while ostensibly allowing a tort remedy, have eliminated what were clearly proximate elements of damages.

This is best illustrated by the cases which held that damages for arrest following dishonor are not recoverable because, as a matter of law, they are not the proximate result of the bank's action. ${ }^{41}$ The reason generally given for this result is that the action of the payee is an intervening cause because it is so unlikely that he would swear out a warrant without further inquiry. ${ }^{42}$ Since issuing a bad check is a crime, it is rather surprising to find the courts holding that arrest following the crime is so improbable that it is not even a question for the jury. ${ }^{43}$

If the action is clearly defined as a tort there is little doubt that the courts would at least leave the question of proximateness to the jury. ${ }^{44}$ This was the

forced into common-law; categories. Injury to reputation, like any other injury, should be compensable but not subject to any special rules.

The courts, following the Rolin case, have in one sense ignored the proper defamation categories. Many of the cases for wrongful dishonor involve all the elements necessary for a libel action, because generally the bank writes or stamps something on the check. However, with the exception of the recent case of Nealis v. Industrial Bank of Commerce, 200 Misc. 406, 107 N.Y.S. 2d 264 (S.Ct., 1951), it has never been held to constitute a libel. Since in libel actions there is a presumption of damages, this decision would vitiate the prevailing New York doctrine that in the absence of malice there is no presumption of damages in wrongful dishonor actions. The significance of the case has apparently gone unnoticed.

${ }^{41}$ Waggoner v. Bank of Bernie, 220 Mo. App. 165, 281 S.W. 130 (1926) ; Hartford v. All Night \& Day Bank, 170 Cal. 538, 150 Pac. 356 (1915).

a Ibid.

"Furthermore it is a question of fact on which there is room for sharp division of opinion. For example, in Bearden v. Bank of Italy, 57 Cal. App. 377, 207 Pac. 270 (1922), the court said that "the issuance of a check ... . without funds or credit to meet it is a public offense which notoriously frequently results in the arrest and imprisonment of the drawer of the check." Ibid., at 378 and 270.

It seems to be, at least indirectly, a contradiction to maintain that arrest following dishonor is somewhat likely after concluding earlier that injury to credit from the dishonor of a check is not too probable. Consult text supra. The explanation is that in neither case is the conclusion as to probability in absolute terms-it is simply that both are proper questions for the jury because in neither case is the injury so likely or unlikely that it should be treated as a question of law.

* The Uniform Commercial Code appears to adopt a third solution which is to hold that as a matter of law dishonor is the proximate cause of arrest. $\$ 4-402$ (Official Draft, 1952); 
thought of the court in the Abramowitz case when it rejected the holding of Hartford v. All Night \& Day Bank $k^{45}$ that an arrest was not the proximate result of a dishonor. The court stated that apparently the Hartford case "assumed that the action before it was one in contract."16 In other words, when a court treats the action entirely as a tort, it must conclude that the arrest was or could be the proximate result of the dishonor. This is supported by the fact that the courts which have treated the action as one entirely in tort have left this question to the jury. ${ }^{47}$

The use of the independent tort measure of damages is also desirable because it harmonizes with the theory that the banks are under a public duty to honor checks drawn against sufficient accounts. This theory was first expounded in Patterson v. Marine Nat'l Bank,48 decided in Pennsylvania in 1889. In that case the court stated that the ordinary rules of contracts should not be applied because:

A bank is an institution of a quasi public character. It is chartered by the government for the purpose, inter alia, of holding and safely keeping the moneys of individuals and corporations. ... Individual and corporate business could hardly exist for a day without banking facilities. At the same time, the business of the community would be at the mercy of banks if they could at their pleasure refuse to honor their depositors' checks, and then claim that such action was the mere breach of an ordinary contract for which only nominal damages could be recovered, unless special damages were proved. There is something more than a breach of contract in such cases. ${ }^{49}$

consult note 38 supra. But varying circumstances may make this result inequitable also; for example, it might be shown that the payee's action was motivated by personal animosity.

¿5 170 Cal. 538, 150 Pac. 356 (1915).

16 Abramowitz v. Bank of America, 131 Cal. App. 2d 892, 897, 281 P. 2d 380, 383 (Super. Ct., 1955).

${ }^{47}$ Collins v. City Nat'l Bank \& Trust Co. of Danbury, 131 Conn. 167, 38 A. 2d 582 (1944); Mouse v. Central Savings \& Trust Co., 120 Ohio St. 599, 167 N.E. 868 (1929). These courts phrased the issue in terms of whether or not the bank's negligence was the proximate cause of the plaintiff's arrest.

It has never been held that negligence must be established in order to recover, although the Collins case contained a dictum to this effect. The necessity of proving negligence could probably be avoided by the use of res ipsa loquitur. This theory is used in actions against telegraph companies for failing to transmit or deliver a message properly. Western Union Telegraph Co. v. Citizen's Bank of Harrison, 144 Ark. 577, 223 S.W. 29 (1920).

The more important question is whether due care, good faith or contributory negligence should be defenses. In the Collins case it was intimated that contributory negligence would be a defense. Contra: Weaver v. Grenada Bank, 180 Miss. 876, 179 So. 564 (1938) (the comparative negligence statute was held inapplicable). See also Johnson v. Nat'l Bank of S.C. of Sumpter, 213 S.C. 458,50 S.E. 2 d 177 (1948). Such defenses should not be allowed. Since the deposit arises out of a contract relationship the situations which might give rise - to a plea of contributory negligence (for instance, where the plaintiff had failed to send in his signature card) can be dealt with in terms of conditions precedent to the duty to honor the check.

130 Pa. 419, 18 Atl. 632 (1889). $\quad$ "Ibid., at 433 and 633. 
A difference in emphasis can be seen between this case and the Rolin case. The English judges were concerned with the plight of the individual depositor because damage to his credit was so likely under their system, whereas the court in the Patterson case emphasized the public character of the bank and the need of greater liability as a means of control.

The Pennsylvania court, however, did not adopt the independent tort theory of damages. It advanced the public policy argument only to justify its use of the presumption of damages. But if the bank is under a public duty to honor checks, a failure to do so is a tort for which any proximate injury should be compensated.50 The defamation rules therefore should have no special application. This result was reached in the subsequent Kentucky case of American Nat'l Bank v. Morey, ${ }^{51}$ where the court, after quoting the above passage from the Patterson case, said that the action had no name and that it:

rests upon the ground that the bank is charged by law with certain duties, and that for a breach of these duties it is liable to the party injured for the damages done him. The measure of these damages is the same as in the case of the breach of other duties imposed by law. ${ }^{52}$

Not only is the independent tort theory a logical development of the publicduty doctrine, it also provides the best measure of damages insofar as the basis of that doctrine is a desire to discipline the banks. We have seen that the contract or foreseeability measure would provide no measure of control if correctly applied. Similarly, the rule of slander, that pecuniary loss must be shown, leads to harsh and inconsistent results. On the other hand, the presumption of damages is not desirable although it leads to an extension of damages. It has no justification in the modern American banking system, and it probably leads to awards beyond the injury sustained. As a means of control it is arbitrary, and since banks generally show a high degree of care already, there is no need to go beyond strictly compensatory damages.

Probably the idea of the check as cash lies behind this public-duty argument with its use of extended liability as a means of disciplining the banks for dishonoring checks.53 Deposit currency and checks are at the center of

${ }^{50}$ Of course the enforcement of all contracts is a matter of public policy. The difference is that society has a greater interest in the proper performance of certain contracts than it has in others. Whenever the legislature decrees by a statute that society has a special interest in a contract the courts impose tort liability. For example, in Western Union Tel. Co. v. Green, 153 Tenn. 59, 281 S.W. 778 (1926), the court held that a statute to the effect that telegraph messages should be delivered correctly and promptly had changed the measure of damages from that of contract to that of tort. Similarly the courts themselves can decide that society has a peculiar interest in a certain type of contract and extend damages from that of contract to that of tort on the basis of public policy.

$$
{ }^{51} 113 \text { Ky. 857, } 69 \text { S.W. } 759 \text { (1902). } \quad{ }^{2} \text { Ibid., at } 864 \text { and } 760 .
$$

${ }^{53}$ That it is the community's reliance on checks as currency which the courts are probably protecting is shown by the fact that they do not hold the banks liable in tort for every in- 
our financial system, and the prompt honoring of checks with the resulting reliance on them is necessary to its proper functioning. The public enjoys the convenience, but the banker makes the profit from this arrangement. He encourages this reliance on checks as cash, so there is nothing strange about putting on him the burden of all the injuries which grow out of this reliance and are caused by his negligence or deliberate dishonors which turn out to be wrongful because he mistook his rights. He is the center of this currency system, profits from it and is in a position to distribute the losses.

If there is a well-defined policy of holding the banks liable for all of the proximate injuries resulting from a wrongful dishonor, as there is under the Abramowitz case, the public can put an even stronger reliance on checkswhich is to the benefit of the community at large, and in the long run, to the bankers.

jury which the depositor suffers. In Stella Flour \& Feed Corp. v. Nat'l City Bank, 285 App. Div. 182, 136 N.Y.S. 2d 139 (1st Dep't, 1954), the plaintiff sued for damages to business and credit suffered as a result of his account being depleted by the bank's negligence in cashing checks on which the payees' names had been changed. The complaint was dismissed on the grounds that to grant tort damages would be pushing responsibility beyond the point where commercial and banking people thought it ended. Cf. Abate v. Bushwick Savings Bank, 207 Misc. 372,138 N.Y.S. 2d 140 (N.Y. City Ct., 1955).

Furthermore, one cannot avoid the liquidated sum rule by making checks out to oneself and presenting them at the bank. In Kinlan v. Ulster Bank, Ltd. [1928] Ir. Rep. 171, the plaintiff had attempted to draw on his account by presenting checks made out to himself. In reply to his suit for wrongful dishonor the court said, "the cause of action on the facts is not the wrongful dishonouring of the plaintiff's cheques, but the wrongful refusal to answer his demand for payment to him out of the moneys standing to the credit of his account. From this point of view, the fact that he produced cheque forms . . . is practically immaterial." Ibid., at 182.

The requirement that there be a third party payee automatically limits recovery to situations where the money was intended for a specific purpose. Otherwise the bank would be liable for all of the speculative losses which might be sustained through a lack of funds. Since these losses would be determined by the depositor's testimony as to how he intended to use his money, the action would encourage speculation and fraud. But compare Jones $v$. Citizen's Bank of Clovis, 58 N.M. 48, 265 P. $2 \mathrm{~d} 366$ (1954). This was an action by an administratrix for loss of credit and mental anxiety leading to the depositor's death. In deciding that a physician's testimony was admissible the court related how the decedent, through lack of funds, was forced to sell his furniture, that his wife had to work, and he could not pay his hospital bills. The court thus improperly merged the damage from lack of funds with those arising directly from the dishonor.

\section{STOCK EXCHANGE MEMBER'S LIABILITY TO CUSTOMER OF OUTSIDE BROKER}

It is settled law that when a person engages another to transact business for him on a particular market the business will be conducted according to any established custom and usage of that market, whether or not the person 